\title{
Further studies on rapid dilution and warming of boar semen
}

\author{
K. Bamba* and D. G. Cran \\ AFRC Institute of Animal Physiology and Genetics Research, Babraham, Cambridge CB2 4AT, \\ U.K.
}

\begin{abstract}
Summary. Studies have been carried out to investigate factors related to the induction of warm shock in boar spermatozoa. Rapid dilution per se caused visible damage to acrosomes when the sample contained $7 \cdot 5 \%$ or more glycerol. This dilution effect was greater at lower temperatures. Acrosomal damage was greatly reduced by raising the dilution temperature from 15 to $25^{\circ} \mathrm{C}$, suggesting that a change in the physico-chemical characteristics of the acrosomal membrane occurred between these temperatures. During rapid dilution with warming, the dilution rate, the magnitude of the temperature change and the terminal temperature had a significant influence on acrosomal integrity; a terminal temperature of $35^{\circ} \mathrm{C}$ was much more detrimental than one of $25^{\circ} \mathrm{C}$. The first sign of acrosomal damage was observed $15 \mathrm{sec}$ after rapid dilution + warming and the damage was nearly maximal by $60 \mathrm{sec}$. An antioxidant, butylated hydroxytoluene(BHT), was effective against both rapid cooling and warming, while glycerol, dimethylsulphoxide and propylene glycol were ineffective in preventing warm shock.
\end{abstract}

Keywords: boar spermatozoa; warming and dilution; acrosome; structure

\section{Introduction}

Boar spermatozoa are severely damaged by warm shock (Bamba \& Cran, 1985). It is likely that this is a very important factor during the thawing of frozen semen. In view of this, it is clear that further studies are required to elucidate the mechanism(s) by which it acts and to find effective conditions for its prevention. The present communication describes a series of experiments designed to examine the effects of temperature, dilution rate, and cryoprotectants on the prevention or initiation of acrosomal damage associated with warm shock.

\section{Materials and Methods}

Semen. Boar semen was collected manually from mature boars and the sperm rich fraction was used. Epididymal spermatozoa were collected by flushing the lower part of each cauda epididymidis with Hülsenberg VIII diluent (Richter et al., $1975 ; 5.75 \mathrm{~g}$ glucose, $0.25 \mathrm{~g}$ lactose, $0.45 \mathrm{~g}$ trisodium citrate dihydrate, $0.35 \mathrm{~g}$ disodium EDTA, $0.12 \mathrm{~g}$ $\mathrm{NaHCO}_{3}$ and $0.04 \mathrm{~g} \mathrm{KCl}$ per $100 \mathrm{ml}$ ). The testes were obtained from freshly slaughtered boars.

Preparation of spermatozoa. Ejaculated semen was processed in basically the same manner as described in the previous report (Bamba \& Cran, 1985). Semen was cooled over 2 h to room temperature $\left(20-25^{\circ} \mathrm{C}\right)$ and diluted with Hülsenberg VIII diluent. Immediately after dilution the sperm suspension was centrifuged at $350 \mathrm{~g}$ for $15 \mathrm{~min}$. Epididymal and ejaculated spermatozoa were then processed in a similar manner. The supernatant was discarded and the spermatozoa were resuspended in BF5 diluent (Pursel \& Johnson, 1975; for details of this and BTS, see report by Bamba \& Cran, 1985). The partly diluted spermatozoa were cooled to $5^{\circ} \mathrm{C}$ over $2 \mathrm{~h}$ and diluted $1: 1$ (v/v) with BF5 diluent containing cryoprotective agent; the dilution was made by adding two equal volumes at 10-min intervals. The diluted semen samples were subjected to experimental treatments immediately.

*Present address: Faculty of Agriculture, Shizuoka University, Shizuoka, Japan. 
Rapid dilution was performed by pipetting $0.2 \mathrm{ml}$ of semen rapidly into a test tube containing $1.6 \mathrm{ml}$ Medium BTS (Pursel \& Johnson, 1975). Unless otherwise stated, the test tube was kept in a water bath at the given temperature. After rapid dilution, the sample was equilibrated to the given temperature for 2 min and then warmed to 35 or $37^{\circ} \mathrm{C}$. Samples were equilibrated for at least $5 \mathrm{~min}$ before evaluation of sperm quality.

Motility was estimated as described by Bamba \& Cran (1985) and was expressed as the percentage of progressively motile spermatozoa. Samples for acrosomal evaluation were diluted 1:1 (v/v) with Medium BTS containing $0.4 \%$ formaldehyde and examined by phase-contrast or differential interference-contrast microscopy at $\times 750$. At least 200 spermatozoa were examined for each sample. Samples before dilution (controls) were diluted $1: 1$ with formol-BTS at the same temperature. Photographs were taken of samples fixed in $1 \%$ glutaraldehyde and $0.4 \%$ formaldehyde.

Samples for electron microscopy were processed as described by Cran et al. (1982).

Replicate tests were made on ejaculates from different boars. Data were subjected to analyses of variance and the differences between treatment means were tested by Tukey's procedure (Steel $\&$ Torrie, 1960).

\section{Results}

\section{Experiment 1: influence of glycerol concentration}

Semen samples containing $0 \cdot 0,1 \cdot 0,2 \cdot 5,5 \cdot 0,7 \cdot 5$ and $10 \cdot 0 \%(\mathrm{v} / \mathrm{v})$ glycerol were rapidly diluted 1:8 (v/v) with Medium BTS as follows: (1) rapid dilution at $5^{\circ} \mathrm{C},(2)$ rapid dilution + warming from 5 to $37^{\circ} \mathrm{C}$ and (3) rapid dilution at $37^{\circ} \mathrm{C}$ after gradual warming. Replicate tests were made on 5 ejaculates.

For all treatments the effect of glycerol was relatively small when at concentrations $<5 \%$. However, significantly lower percentages of normal acrosomes were present after dilution at $5^{\circ} \mathrm{C}$ with 7.5 or $10 \%$ glycerol (Table 1). The appearance of the damaged spermatozoa was similar to that following warm shock (Fig. 3). Rapid dilution at $37^{\circ} \mathrm{C}$ also resulted in acrosomal damage but this was not as severe as that following dilution at $5^{\circ} \mathrm{C}$ and it was further clear that the inclusion of glycerol did not prevent warm shock following rapid temperature elevation. The proportion of normal acrosomes was also lower following gradual warming regardless of glycerol concentration. As shown in Figs 1 and 2 the inclusion of 1 or $10 \%$ glycerol at $5^{\circ} \mathrm{C}$ did not result in vesiculation of the acrosomes. However, the apical ridges appeared to be slightly flattened and there were slight signs of invagination of the outer acrosomal membrane at a concentration of $10 \%$ glycerol. Acrosomal vesiculation took place in response to warm shock regardless of glycerol concentration.

Table 1. Effects of glycerol concentration and temperature on acrosomal morphology in rapid dilution treatments

\begin{tabular}{|c|c|c|c|c|c|c|}
\hline \multirow{2}{*}{$\begin{array}{l}\text { Glycerol } \\
(\%)\end{array}$} & \multirow{2}{*}{$\begin{array}{l}\text { Temperature of semen: } \\
\text { Temperature of Medium BTS: }\end{array}$} & \multicolumn{3}{|c|}{$5^{\circ} \mathrm{C}$} & \multicolumn{2}{|c|}{$37^{\circ} \mathrm{C}$} \\
\hline & & Control & $5^{\circ} \mathrm{C}$ & $37^{\circ} \mathrm{C}$ & Control & $37^{\circ} \mathrm{C}$ \\
\hline 0 & & 93.4 & $89 \cdot 6$ & $10 \cdot 0$ & $91 \cdot 0$ & $84 \cdot 0$ \\
\hline 1.0 & & $94 \cdot 6$ & $89 \cdot 2$ & $10 \cdot 2$ & $90 \cdot 0$ & 85.6 \\
\hline $2 \cdot 5$ & & 93.4 & 88.0 & 8.4 & $88 \cdot 6$ & $87 \cdot 4$ \\
\hline $5 \cdot 0$ & & 92.4 & 81.8 & 8.4 & $87 \cdot 2$ & $84 \cdot 6$ \\
\hline $7 \cdot 5$ & & $91 \cdot 8$ & $52 \cdot 6^{* * *}$ & $6 \cdot 2$ & 85.8 & $77 \cdot 6$ \\
\hline $10 \cdot 0$ & & $88 \cdot 4$ & $6 \cdot 8^{* *}$ & $3 \cdot 2$ & $84 \cdot 4$ & $58 \cdot 6^{* *}$ \\
\hline
\end{tabular}

Values are mean $\%$ of normal acrosomes for 5 observations.

**Significantly different from $0 \%$ glycerol value $(P<0.01)$.

\section{Experiment 2: influence of the temperature of rapid dilution and glycerol concentration}

Semen samples containing 1 or $10 \%$ glycerol were warmed gradually in a stepwise fashion from 5 to 15 to 25 to $37^{\circ} \mathrm{C}$ with $5 \mathrm{~min}$ at each temperature. At each temperature, the samples were rapidly diluted 1:8 (v/v) with Medium BTS at the same temperature as the samples. Replicate tests were made on 5 ejaculates. 
Table 2. Effects of rapid dilution at various temperatures on acrosomal morphology

\begin{tabular}{llc}
\hline & \multicolumn{2}{c}{$\begin{array}{c}\text { Glycerol } \\
\text { concentration }\end{array}$} \\
\cline { 2 - 3 } $\begin{array}{l}\text { Temperature of } \\
\text { dilution }\end{array}$ & $1 \%$ & $10 \%$ \\
\hline Before dilution $\left(5^{\circ} \mathrm{C}\right)$ & $90 \cdot 2$ & $84 \cdot 8$ \\
Dilution at: $5^{\circ} \mathrm{C}$ & $88 \cdot 4$ & $4 \cdot 4^{* *}$ \\
$15^{\circ} \mathrm{C}$ & $86 \cdot 6$ & $9 \cdot 2^{* *}$ \\
$25^{\circ} \mathrm{C}$ & $84 \cdot 0$ & $46 \cdot 2^{* *}$ \\
$37^{\circ} \mathrm{C}$ & $78 \cdot 8^{*}$ & $57 \cdot 8^{* *}$ \\
After gradual warming $\left(37^{\circ} \mathrm{C}\right)$ & $82 \cdot 8$ & $81 \cdot 0$ \\
\hline
\end{tabular}

Values are mean $\%$ of normal acrosomes for 5 observations.

Statistically significant from the value for before dilution at $5^{\circ} \mathrm{C}\left({ }^{*} P<0.05,{ }^{* *} P<0.01\right)$.

Table 3. Time course of acrosomal change after rapid dilution + warming treatment

\begin{tabular}{lc}
\hline $\begin{array}{l}\text { Incubation time } \\
\text { after dilution }\end{array}$ & $\%$ normal acrosomes \\
\hline Control (before dilution) & $94 \cdot 5$ \\
0 sec & $92 \cdot 7$ \\
15 & $74 \cdot 7^{* *}$ \\
60 & $22 \cdot 0^{* *}$ \\
300 & $10 \cdot 5^{* *}$ \\
\hline
\end{tabular}

Values are means for 4 observations.

**Significantly different from control value $(P<0.01)$.

In the samples containing $1 \%$ glycerol the proportion of normal acrosomes decreased with a rise in the dilution temperature (Table 2). However, in those samples containing $10 \%$ glycerol there was a marked effect on acrosomal integrity which was ameliorated with temperature elevation. Rapid dilution at 5,15 and $25^{\circ} \mathrm{C} \mathrm{(Fig.} \mathrm{4)} \mathrm{induced} \mathrm{vesiculation} \mathrm{in} \mathrm{semen} \mathrm{containing} 10 \%$ glycerol.

\section{Experiment 3: time course of acrosomal change after rapid warming}

Semen samples containing $1 \%(\mathrm{v} / \mathrm{v})$ glycerol were rapidly diluted 1:8 (v/v) with Medium BTS at $37^{\circ} \mathrm{C}$. After $0,15,60$ and $300 \mathrm{sec}$ from dilution they were fixed $1: 1$ with the primary fixative used for electron microscopy ( $2 \%$ glutaraldehyde, $1 \%$ formaldehyde, $0 \cdot 2 \mathrm{M}$-sucrose, $1.5 \mathrm{mM}-\mathrm{CaCl}_{2}$ in $0 \cdot 1$ M-cacodylate buffer, $\mathrm{pH} 7 \cdot 3$ ). Replicate tests were made on 4 ejaculates.

At $15 \mathrm{sec}$ following treatment there was a significant decrease in the number of normal acrosomes which reached maximal values by $300 \mathrm{sec}$ (Table 3). At the level of the electron microscope it was evident that the first signs of invagination of the outer acrosomal membrane were present by $15 \mathrm{sec}$ (Fig. 5). At $60 \mathrm{sec}$ the spermatozoa had the full complement of structural features associated with warm shock.

\section{Experiment 4: influence of dilution rate}

Semen samples $(0.2 \mathrm{ml})$ containing 1 and $10 \%$ glycerol at $5^{\circ} \mathrm{C}$ were quickly pipetted into thinwalled test tubes containing $0-1.6 \mathrm{ml}$ Medium BTS at $37^{\circ} \mathrm{C}$. Replicate tests were made on 4 ejaculates. 
1
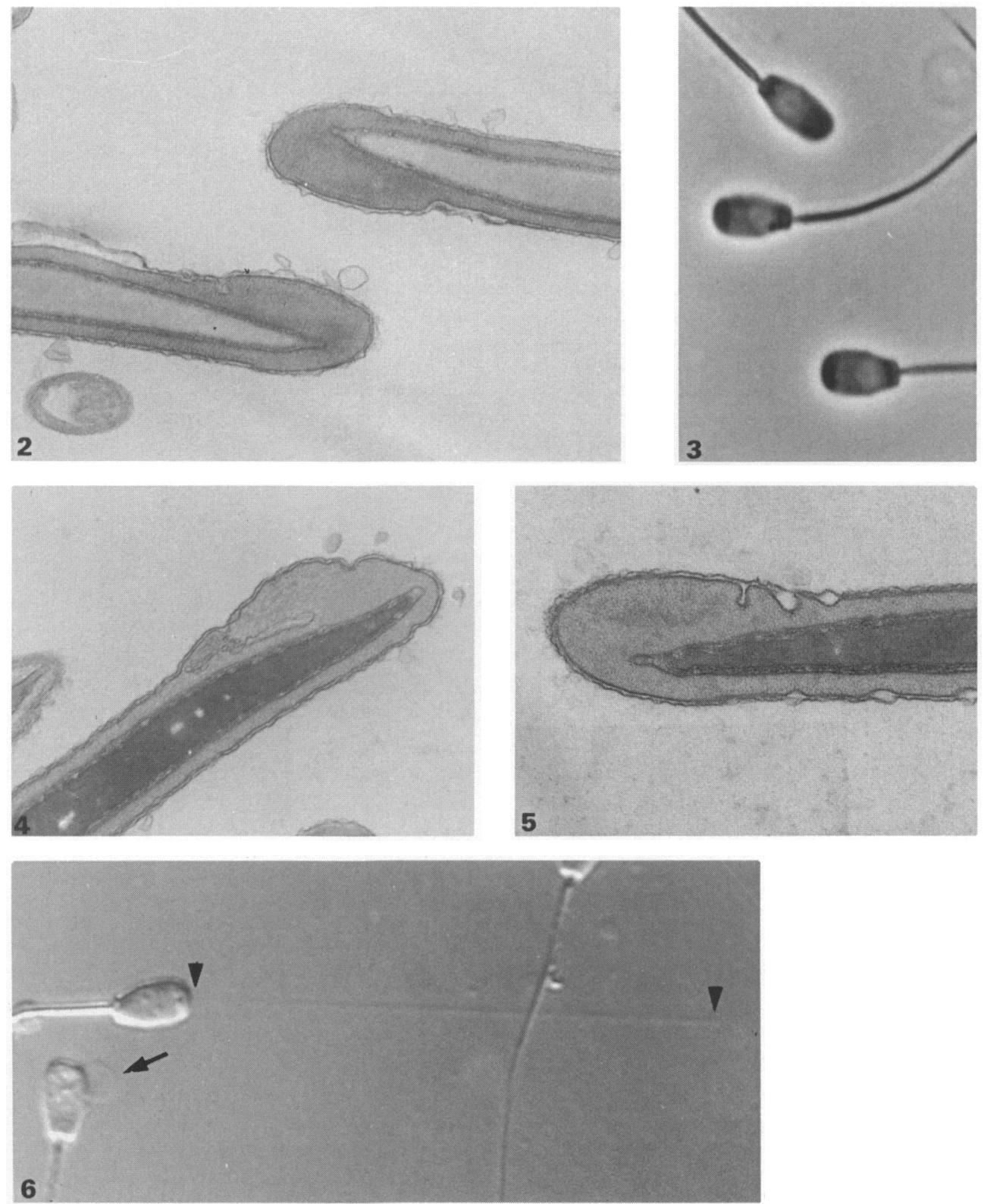
While in such an experiment it is difficult to distinguish between the effect of temperature and the degree of dilution, nevertheless it was clear that as the degree of dilution increased there was a higher percentage of acrosomal damage (Table 4). As in previous experiments a detrimental effect of a high glycerol concentration was observed.

\section{Experiment 5: influence of the magnitude of temperature change and temperature zone}

Semen samples containing $1 \%$ glycerol were warmed in a stepwise fashion from 5 to 15 to 25 to $35^{\circ} \mathrm{C}$. At each temperature, semen samples were rapidly diluted $1: 8(\mathrm{v} / \mathrm{v})$ with Medium BTS at 5 , 15,25 and $35^{\circ} \mathrm{C}$. In this manner temperature differentials ranging from +30 to $-30^{\circ} \mathrm{C}$ were achieved. Replicate tests were made on 6 ejaculated and 6 epididymal sperm samples.

The acrosomes of ejaculated and epididymal spermatozoa showed basically similar responses to the rapid temperature changes together with dilution (Table 5). However, epididymal spermatozoa were rather more sensitive to these stresses than were those in ejaculates. While the percentage of normal acrosomes decreased slightly during gradual warming from 5 to $35^{\circ} \mathrm{C}$ this did not approach significance. In treatments in which the spermatozoa were subjected to an increase or decrease in temperature the degree of integrity of the acrosomes was influenced by the magnitude of the temperature differential and the temperature zone. When treatments with the same temperature change were compared, acrosomal damage tended to occur at a higher temperature zone during warming and at a lower zone during cooling. Rapid warming from 5 to $35^{\circ} \mathrm{C}$ resulted in the greatest degree of acrosomal damage even more than that found after cooling through the same temperature differential. The mean percentage of motility was unaffected by rapid warming but decreased significantly after rapid cooling from 35 to $5^{\circ} \mathrm{C}$ (ejaculated and epididymal spermatozoa, $P<0.01$ ) and from 25 to $5^{\circ} \mathrm{C}$ (ejaculated spermatozoa, $P<0.05$ ).

\section{Experiment 6: immunocytochemical detection of acrosomal damage after temperature shocks}

Semen samples containing $1 \%$ glycerol at $5^{\circ} \mathrm{C}$ and those warmed gradually to $37^{\circ} \mathrm{C}$ were rapidly diluted 1:8 (v/v) with Medium BTS at 5 and $37^{\circ} \mathrm{C}$. After rapid dilution, the samples were incubated at $37^{\circ} \mathrm{C}$ for $2 \mathrm{~h}$. Smears were made at the beginning and at the end of the incubation, and detection of acrosomal damage was carried out as described by Harrison \& Fléchon (1980). At least 200 spermatozoa were examined and categorized into those which were fluorescent (acrosin positive) and those which were not (acrosin negative). Those cells categorized as being acrosinpositive ranged from having weak to strong fluorescence. Replicate tests were made on 4 ejaculates.

Fig. 1. Spermatozoon with a normal apical ridge. TEM, $\times 26500$.

Fig. 2. Spermatozoa diluted in BF5 diluent containing $10 \%$ glycerol at $5^{\circ} \mathrm{C}$. Note flattened apical ridge and a slight sign of invagination. TEM, $\times 29250$.

Fig. 3. Spermatozoa after rapid dilution at $5^{\circ} \mathrm{C}$ (the spermatozoa in BF5 containing $10 \%$ glycerol were diluted rapidly with BTS medium at $5^{\circ} \mathrm{C}$ ). Note the loss of apical ridge and a dark area in anterior part of head. Phase contrast, $\times 1250$.

Fig. 4. Spermatozoon after rapid dilution at $5^{\circ} \mathrm{C}$ (the spermatozoon was treated as in Fig. 3). Note prominent invagination and ruffling of outer acrosomal membrane. TEM, $\times 34000$.

Fig. 5. Spermatozoon after $15 \mathrm{sec}$ of rapid dilution + warming. The appearance is similar to that of spermatozoa in Fig. 2. Small invaginations are visible. TEM, $\times 45000$.

Fig. 6. Warm-shocked spermatozoa with filament-like (arrow heads show both ends) or dropletlike (arrow) particle. Nomarski, $\times 1250$. 
Table 4. Effects of dilution rates on acrosomal morphology in rapid dilution + warming treatments

\begin{tabular}{lcc}
\hline & \multicolumn{2}{c}{$\begin{array}{c}\text { Concentration of } \\
\text { glycerol }\end{array}$} \\
\cline { 2 - 3 } Treatment & $1 \%$ & $10 \%$ \\
\hline Before dilution $\left(5^{\circ} \mathrm{C}\right)$ & $91 \cdot 5$ & $89 \cdot 5$ \\
Slow warming to $37^{\circ} \mathrm{C}$ & $87 \cdot 2$ & $82 \cdot 7$ \\
Dilution rate (semen:BTS) & & \\
$1: 0$ & $81 \cdot 7$ & $71 \cdot 1$ \\
$1: 1$ & $70 \cdot 5$ & $42 \cdot 7$ \\
$1: 2$ & $39 \cdot 2^{* *}$ & $20 \cdot 5^{* *}$ \\
$1: 4$ & $17 \cdot 5^{* *}$ & $5 \cdot 0^{* *}$ \\
$1: 8$ & $5 \cdot 0^{* *}$ & $1 \cdot 5^{* *}$ \\
\hline
\end{tabular}

Values are means of $\%$ normal acrosomes for 4 observations.

**Significantly different from values before dilution $(P<0.01)$.

Table 5. Effects of temperature of semen and Medium BTS on acrosomal morphology in rapid dilution treatments

\begin{tabular}{|c|c|c|c|c|}
\hline \multicolumn{3}{|c|}{ Temperature $\left({ }^{\circ} \mathrm{C}\right)$} & \multicolumn{2}{|c|}{$\%$ normal acrosomes } \\
\hline Semen & BTS & Difference & $\begin{array}{l}\text { Ejaculated } \\
\text { sperm. }\end{array}$ & $\begin{array}{l}\text { Epididymal } \\
\text { sperm. }\end{array}$ \\
\hline 5 & - & Control & 94.0 & 93.6 \\
\hline 15 & - & (before dilution) & $92 \cdot 0$ & 91.6 \\
\hline 25 & - & & 92.8 & $91 \cdot 5$ \\
\hline 35 & - & & $90 \cdot 8$ & 87.8 \\
\hline 5 & 5 & 0 & $91 \cdot 3$ & $87 \cdot 5^{*}$ \\
\hline 15 & 15 & & $90 \cdot 0$ & $82 \cdot 8^{* *}$ \\
\hline 25 & 25 & & 87.6 & 81.8 \\
\hline 35 & 35 & & 86.5 & $80 \cdot 1$ \\
\hline 5 & 15 & +10 & $90 \cdot 6$ & $83 \cdot 8^{* *}$ \\
\hline 15 & 25 & & 89.6 & $81 \cdot 0^{* *}$ \\
\hline 25 & 35 & & $76 \cdot 3^{* *}$ & $65 \cdot 8^{* *}$ \\
\hline 15 & 5 & -10 & $85 \cdot 6$ & $82 \cdot 3 * *$ \\
\hline 25 & 15 & & 88.8 & $83 \cdot 0$ \\
\hline 35 & 25 & & $84 \cdot 1$ & $71 \cdot 6^{*}$ \\
\hline 5 & 25 & +20 & $86 \cdot 1^{* *}$ & $74 \cdot 0^{* *}$ \\
\hline 15 & 35 & & $18 \cdot 6^{* *}$ & $4 \cdot 1^{* *}$ \\
\hline 25 & 5 & -20 & $64 \cdot 0^{* *}$ & $59 \cdot 8^{* *}$ \\
\hline 35 & 15 & & $80 \cdot 5$ & $68 \cdot 6^{*}$ \\
\hline 5 & 35 & +30 & $14 \cdot 8^{* *}$ & $4 \cdot 0^{* *}$ \\
\hline 35 & 5 & -30 & $24 \cdot 5^{* *}$ & $25 \cdot 6 * *$ \\
\hline
\end{tabular}

Values are means for 6 observations.

${ }^{*} P<0.05,{ }^{* *} P<0.01$ compared with control value for that semen temperature. 
Table 6. Effects of rapid dilution treatments on acrosin release

\begin{tabular}{llccc}
\hline Incubation & Treatment & $\begin{array}{c}\text { Acrosin } \\
\text { positive }\end{array}$ & $\begin{array}{c}\text { Normal } \\
\text { acrosomes }\end{array}$ & Motility \\
\hline $0 \mathrm{~h}$ & Rapid dilution at $5^{\circ} \mathrm{C}$ & $93 \cdot 7$ & $95 \cdot 1$ & $90 \cdot 0$ \\
& Rapid dilution + warming & $92 \cdot 5$ & $3 \cdot 7^{* *}$ & $90 \cdot 0$ \\
& Rapid dilution at $37^{\circ} \mathrm{C}$ & $93 \cdot 0$ & $90 \cdot 6$ & $90 \cdot 0$ \\
& Rapid dilution + cooling & $60 \cdot 1^{*}$ & $14 \cdot 1^{* *}$ & $18 \cdot 7^{* *}$ \\
& Rapid dilution at $5^{\circ} \mathrm{C}$ & $91 \cdot 0$ & $84 \cdot 7$ & $87 \cdot 5$ \\
& Rapid dilution + warming & $68 \cdot 3$ & $1 \cdot 0^{* *}$ & $85 \cdot 0$ \\
& Rapid dilution at $37^{\circ} \mathrm{C}$ & $90 \cdot 1$ & $77 \cdot 3$ & $87 \cdot 5$ \\
& Rapid dilution + cooling & $20 \cdot 7^{* *}$ & $2 \cdot 8^{* *}$ & $12 \cdot 5^{* *}$ \\
\hline
\end{tabular}

Each value is the mean $\%$ of 4 observations.

${ }^{*} P<0.05,{ }^{* *} P<0.01$ compared with values for rapid dilution at $5^{\circ} \mathrm{C}$.

Table 7. Effects of cryoprotective agents (G, glycerol; D, DMSO; P, propylene glycol) on motility and acrosomal morphology in rapid dilution treatments

\begin{tabular}{|c|c|c|c|c|c|c|}
\hline \multirow[b]{2}{*}{ Treatment } & \multicolumn{3}{|c|}{ Motility } & \multicolumn{3}{|c|}{ Normal acrosomes } \\
\hline & $\mathrm{G}$ & D & $\mathbf{P}$ & $\mathbf{G}$ & D & $\mathbf{P}$ \\
\hline Rapid dilution at $5^{\circ} \mathrm{C}$ & $89 \cdot 0$ & $66 \cdot 0^{* *}$ & $89 \cdot 0$ & $87 \cdot 4$ & $84 \cdot 4$ & $85 \cdot 4$ \\
\hline Rapid dilution + warming & 89.0 & $89 \cdot 0$ & $89 \cdot 0$ & $3 \cdot 0$ & $3 \cdot 2$ & $3 \cdot 6$ \\
\hline Rapid dilution at $37^{\circ} \mathrm{C}$ & $89 \cdot 0$ & $89 \cdot 0$ & $89 \cdot 0$ & $79 \cdot 0$ & $79 \cdot 4$ & $81 \cdot 0$ \\
\hline Rapid dilution + cooling & $15 \cdot 0$ & $10 \cdot 0$ & $12 \cdot 0$ & $6 \cdot 2$ & 3.6 & $5 \cdot 0$ \\
\hline
\end{tabular}

Each value is the mean $\%$ of 5 observations.

${ }^{* *} P<0.01$ compared with value for $\mathrm{G}$.

Rapid dilution + cooling resulted in an immediate reduction of acrosin-positive spermatozoa with a further decrease after $2 \mathrm{~h}$ incubation (Table 6). There was no change in the percentage of acrosin-positive spermatozoa immediately following rapid dilution + warming. However, after incubation for $2 \mathrm{~h}$ the number fell to some $75 \%$ of the control level.

\section{Experiment 7: influence of cryoprotective agents}

Semen samples containing $1 \%(\mathrm{v} / \mathrm{v})$ glycerol, dimethyl sulphoxide (DMSO), or propylene glycol at $5^{\circ} \mathrm{C}$ were rapidly diluted $1: 8(\mathrm{v} / \mathrm{v})$ with Medium BTS at 5 and $37^{\circ} \mathrm{C}$. Rapid dilution was also made on samples gradually warmed to $37^{\circ} \mathrm{C}$. Replicate tests were made on 5 ejaculates.

None of the cryoprotectants significantly reduced the incidence of the damage resulting from warm shock (Table 7). In addition, only DMSO had a significant effect $(P<0.01)$ on motility following rapid dilution at $5^{\circ} \mathrm{C}$.

\section{Experiment 8: influence of butylated hydroxytoluene (BHT)}

Ejaculated semen was diluted 1:1 (v/v) with Medium BTS immediately after collection. The partly diluted semen was further diluted 1:1 (v/v) with (1) Medium BTS, (2) Medium BTS containing 2\% (v/v) DMSO, and (3) Medium BTS containing 2\% DMSO and 4 mM-butylated hydroxytoluene $(\mathrm{BHT})$ at $37^{\circ} \mathrm{C}$; they were added in two equal portions $10 \mathrm{~min}$ apart. The diluted semen samples were further incubated at $37^{\circ} \mathrm{C}$ for $20 \mathrm{~min}$, and then rapidly diluted 1:8(v/v) with Medium BTS at 5 
Table 8. Effects of BHT and DMSO on motility and acrosomal morphology in rapid dilution treatments

\begin{tabular}{|c|c|c|c|c|c|c|}
\hline \multirow[b]{2}{*}{ Treatment } & \multicolumn{3}{|c|}{ Motility } & \multicolumn{3}{|c|}{ Normal acrosomes } \\
\hline & None & DMSO & $\begin{array}{c}\text { DMSO } \\
+ \text { BHT } \dagger\end{array}$ & None & DMSO & $\begin{array}{l}\text { DMSO } \\
+ \text { BHT }\end{array}$ \\
\hline Control at $37^{\circ} \mathrm{C}$ & $90 \cdot 0$ & $87 \cdot 5$ & $0(10 \cdot 1)$ & 97.8 & 97.5 & $96 \cdot 7$ \\
\hline Rapid dilution + cooling & 0 & $0 \cdot 2$ & $0(0)$ & 0 & 0 & $73 \cdot 0^{* *}$ \\
\hline Control at $5^{\circ} \mathrm{C}$ & $77 \cdot 5$ & $78 \cdot 7$ & $0(11 \cdot 2)$ & $91 \cdot 0$ & $89 \cdot 5$ & 90.7 \\
\hline Rapid dilution + warming & $71 \cdot 2$ & $78 \cdot 7$ & $0(8 \cdot 7)$ & 13.8 & $16 \cdot 3$ & $60 \cdot 6^{* *}$ \\
\hline
\end{tabular}

Each value is the mean $\%$ of 4 observations.

${ }^{*} * P<0.01$ compared with value for no treatment.

†Although progressive motility was not observed in the presence of BHT, some spermatozoa were slightly motile (values in the parentheses are the means of $\%$ motile spermatozoa).

and $37^{\circ} \mathrm{C}$. Rapid dilution was also made on the samples cooled down to $5^{\circ} \mathrm{C}$ gradually. Replicate tests were made on 4 ejaculates.

The addition of BHT to the medium had a profound effect on the motility of spermatozoa (Table 8). While some cells maintained a slight degree of motility, progressive motility was abolished. On the other hand, there was a clear protective influence against acrosomal damage sustained during both warm and cold shock.

\section{Discussion}

It has been established that boar spermatozoa are adversely affected by the presence of high concentrations of glycerol (Polge, 1978). In the present study, the effects of rapid dilution and warming were first examined in relation to glycerol concentration. Although the decrease in the proportion of normal acrosomes due to the inclusion of $10 \%$ glycerol was comparatively small, there were slight alterations in the apical ridges at this concentration as seen by transmission electron microscopy. It is possible that such altered acrosomes would have an increased sensitivity to osmotic or temperature shock. On the other hand, pronounced acrosomal damage was observed when samples containing $7 \cdot 5$ or $10 \%$ glycerol were rapidly diluted at 5 and $15^{\circ} \mathrm{C}$. This damage was reduced as the temperature of dilution was raised, particularly from 15 to $25^{\circ} \mathrm{C}$, indicating a change in the permeability of the outer acrosomal membrane to cryoprotectants presumably through the phase transition of the membrane lipids at these temperatures. However, visible acrosomal damage was still observed in samples containing $10 \%$ glycerol after rapid dilution at $37^{\circ} \mathrm{C}$.

Similar temperature-dependent effects of rapid dilution have been noted in human red blood cells (Woolgar \& Morris, 1973), mouse lymph node cells (Thorpe et al., 1976) and mouse embryos (Whittingham et al., 1979). In the case of sperm cells, the removal of high concentrations of glycerol should be done gradually at temperatures above $25^{\circ} \mathrm{C}$ to minimize osmotic shock. When glycerol levels were lower than $2.5 \%$, the effect of rapid dilution was relatively small regardless of the dilution temperature, suggesting that acrosomal damage caused by rapid dilution + warming could largely be attributed to the warming component at low glycerol concentrations. In contrast, both warming and dilution components are important factors affecting acrosomal integrity in samples containing high glycerol concentrations.

The dilution rate was an important factor during rapid dilution and warming. The proportion of normal acrosomes decreased significantly at a dilution rate of $1: 2$ and acrosomal damage increased with increasing rates of dilution, which is likely to be due to the increased rates of warming as far as samples containing low concentrations of glycerol were concerned. In addition, it was shown that a 
terminal temperature of $35^{\circ} \mathrm{C}$ was much more detrimental to acrosomes than one of $25^{\circ} \mathrm{C}$. On thawing pellets in solution, attention should be given to its volume and initial temperature such that the terminal temperature of the thawed semen does not exceed $25^{\circ} \mathrm{C}$.

During slow warming of semen from 5 to 35 or $37^{\circ} \mathrm{C}$, the proportion of normal acrosomes decreased by some $5 \%$ in samples containing $1 \%$ glycerol (Table 1, 2, 4 and 5). In addition, pipetting $0.2 \mathrm{ml}$ of semen at $5^{\circ} \mathrm{C}$ into a test tube at $37^{\circ} \mathrm{C}$ caused a reduction in the percentage of normal acrosomes. Such an injurious effect of warming would be inevitable when pellets are thawed on a hot plate or straws thawed in hot water. Pursel \& Park (1985) reported that the highest percentage of motility and normal acrosomes were observed when a 5 -ml straw was thawed by immersion in a water bath at $52^{\circ} \mathrm{C}$ for $40 \mathrm{sec}$ (terminal temperature; $15 \cdot 2^{\circ} \mathrm{C}$ ). It is likely that the terminal temperature is an important factor when thawing semen without a thawing solution.

To prevent warm shock it is preferable to include a protective agent in the diluent. It has been shown that BHT, an antioxidant, protected bull (Hammerstedt et al., 1978), ram (Hammerstedt $e t$ al., 1978; Watson \& Anderson, 1983) and boar (Pursel, 1979) spermatozoa from cold shock. In the present study this proved to be effective in preventing acrosomal damage resulting from both cold and warm shock. The use of BHT might, therefore, be one approach for the prevention of warm shock during rapid thawing of frozen semen. However, since BHT adversely affects sperm motility, further studies on its use are required. On the other hand, permeable cryoprotective agents such as glycerol, propylene glycol and DMSO were ineffective against warm shock.

Epididymal spermatozoa were more sensitive to warming stress than those in the ejaculate. With regard to susceptibility to cold shock in the boar a complex interaction exists between the spermatozoa and the seminal fluid (Watson, 1981). Susceptibility to cold shock occurs in the distal corpus epididymidis (Watson \& Plummer, 1985). Since the epididymal spermatozoa used in this study were collected from the cauda epididymidis, the inherent characteristics of these cells may be similar to those in the ejaculate. Therefore, seminal plasma may be involved in the differences in susceptibility to warm shock.

After rapid dilution + warming, acrosomal vesiculation commenced within $15 \mathrm{sec}$ and was nearly maximal by $60 \mathrm{sec}$. However, the membranes of such warm shocked spermatozoa did appear to be altered since subsequent incubation for $2 \mathrm{~h}$ at $37^{\circ} \mathrm{C}$ resulted in release of acrosin. In addition, cells with a filament and/or droplet-like structure were frequently observed after storage of warm shocked cells in the fixative at $4^{\circ} \mathrm{C}$ overnight. It is suggested that matrix materials within the acrosome were released through small punctate ruptures in the membranes. In cold-shocked spermatozoa such structures were not observed, possibly since the membrane damage was so great that release of acrosomal contents occurred abruptly.

Although a full understanding of warm shock may require a biophysical approach, the present study has indicated some avenues which may provide improvements in current techniques of freezing and thawing boar semen.

We thank Dr R. A. P. Harrison for his assistance in immunocytochemical detection of acrosin.

\section{References}

Bamba, K. \& Cran, D.G. (1985) Effect of rapid warming of boar semen on sperm morphology and physiology. J. Reprod. Fert. 75, 133-138.

Cran, D.G., Dott, H.M. \& Wilmington, J.W. (1982) The structure and formation of rolled and crested bull spermatozoa. Gamete Res. 5, 263-269.

Hammerstedt, R.H., Keith, A.C., Snipes, W., Amann, R.P., Arruda, D. \& Griel, L.C., Jr (1978) Use of spin labels to evaluate effects of cold shock and osmolality on sperm. Biol. Reprod. 18, 686-696.

Harrison, R.A.P. \& Fléchon, J.E. (1980) Immunocyto- chemical detection of acrosomal damage following cold shock: loss of acrosin from the acrosomal region of ram, bull and boar spermatozoa. Reprod. Nutr. Dévelop. 20, 1801-1810.

Polge, C. (1978) Fertilization in the pig and horse. $J$. Reprod. Fert. 54, 461-470.

Pursel, V.G. (1979) Effect of cold shock on boar sperm treated with butylated hydroxytoluene. Biol. Reprod. 21, 319-324.

Pursel, V.G. \& Johnson, L.A. (1975) Freezing of boar spermatozoa: fertilizing capacity with concentrated 
semen and a new thawing procedure. J. Anim. Sci.40, 99-102.

Pursel, V.G. \& Park, C.S. (1985) Freezing and thawing procedures for boar spermatozoa. Proc. Ist Int. Conf. Deep Freezing of Boar Semen, Uppsala, 147-166.

Richter, L., Romeny, E., Weitze, K.F. \& Zimmermann, F. (1975) Deep freezing of boar semen. Laboratory and field experiments using the extender Hülsenberg VIII. Disch. Tierärztl. Wschr. 82, 155-162.

Steel, R.G.D. \& Torrie, J.H. (1960) Principles and Procedures of Statistics. McGraw-Hill Book Co., New York.

Thorpe, P.E., Knight, S.C. \& Farrant, J. (1976) Optimal conditions for the preservation of mouse lymph node cells in liquid nitrogen using cooling rate techniques. Cryobiology 13, 126-133.

Watson, P.F. (1981) The effects of cold shock on sperm cell membranes. In Effects of Low Temperatures on Biological Membranes, pp. 189-218. Eds G. J. Morris \& A. Clarke. Academic Press, London.
Watson, P.F. \& Anderson, W.J. (1983) Influence of butylated hydroxytoluene (BHT) on the viability of ram spermatozoa undergoing cold shock. J. Reprod. Fert. 69, 229-235.

Watson, P.F. \& Plummer, J.M. (1985) The responses of boar sperm membranes to cold shock and cooling. Proc. 1st. Int. Conf. Deep Freezing of Boar Semen, Uppsala, 113-127.

Whittingham, D.G., Wood, M., Farrant, J., Lee, H. \& Halsey, J.A. (1979) Survival of frozen mouse embryos after rapid thawing from $-196^{\circ} \mathrm{C}$. J. Reprod. Fert. 56, 11-21.

Woolgar, A.E. \& Morris, G.J. (1973) Some combined effects of hypertonic solutions and changes in tem. perature on posthypertonic hemolysis of human red blood cells. Cryobiology 10, $82-86$.

Received 15 May 1987 